\title{
Measuring the social sustainability of new housing development: a critical review of assessment methods
}

Article

Published Version

Creative Commons: Attribution 4.0 (CC-BY)

Open Access

Dixon, T. (2019) Measuring the social sustainability of new housing development: a critical review of assessment methods. Journal of Sustainable Real Estate, 11 (1). pp. 1639. doi: https://doi.org/10.22300/1949-8276.11.1.16 Available at http://centaur.reading.ac.uk/82774/

It is advisable to refer to the publisher's version if you intend to cite from the work. See Guidance on citing.

Published version at: https://www.tandfonline.com/doi/abs/10.22300/1949-8276.11.1.16

Identification Number/DOI: https://doi.org/10.22300/1949-8276.11.1.16

<https://doi.org/10.22300/1949-8276.11.1.16>

Publisher: American Real Estate Society

All outputs in CentAUR are protected by Intellectual Property Rights law, including copyright law. Copyright and IPR is retained by the creators or other copyright holders. Terms and conditions for use of this material are defined in the End User Agreement. 


\section{www.reading.ac.uk/centaur}

\section{CentAUR}

Central Archive at the University of Reading

Reading's research outputs online 


\section{Journal of Sustainable Real Estate}

\section{Measuring the Social Sustainability of New Housing Development: A Critical Review of Assessment Methods}

\section{Tim Dixon}

To cite this article: Tim Dixon (2019) Measuring the Social Sustainability of New Housing

Development: A Critical Review of Assessment Methods, Journal of Sustainable Real Estate, 11:1, 16-39

To link to this article: https://doi.org/10.22300/1949-8276.11.1.16

\section{() 2019 American Real Estate Society}

曲 Published online: 18 Jun 2020.

Submit your article to this journal 주

山 Article views: 2

Q View related articles $ک$

View Crossmark data $\asymp$ 


\section{Measuring the Social \\ Sustainability of New Housing \\ Development: A Critical Review \\ of Assessment Methods}

A uthor

Abstract

Tim Dixon

Social sustainability is a growing area of debate in the built environment, particularly in relation to housing. Homebuilders in the United Kingdom have responded to organizational and policy drivers by developing ex post assessment frameworks to measure the social sustainability of new housing development. In this paper, I offer a critical perspective of these frameworks by: (1) examining the origins of the concept of social sustainability at the neighborhood level; (2) analyzing the critical challenges and research questions about social sustainability that the underlying methodologies raise; and, (3) how such frameworks might be improved and developed further.

Ke y w o r d s social sustainability; housing; sustainable communities; neighborhood, urban design

Over the last 30 years, the concept of "social sustainability" has been debated and discussed extensively in a wide range of the academic literature from different disciplines, but with little consensus as to its precise meaning or measurement (Colantonio and Dixon, 2011; Shirazi and Keivani, 2017). This can also be viewed as part of the wider debate as to whether there is an equivalence over the way that the built environment profession deals with the three main elements of sustainability: namely, the environmental, economic, and social dimensions (Wilkinson, 2006). Broadly speaking, much of the literature has focused on defining social sustainability in terms of such elements as "well-being," "social cohesion," "social equity," and "social capital." In the more specific built environment literature, the focus has tended to be on examining the links between urban design, infrastructure and amenities ("physical factors"), and the way people feel and react to their environment ("non-physical") at a variety of scales: for example, "building," "neighborhood"/ "community," and "city" (Dempsey, Bramley, Power, and Brown, 2011; Woodcraft, Hackett, and Caistor-Arendar, 2011; Dixon and Woodcraft, 2013).

Social sustainability continues, however, to remain a "contested" concept, and yet, within the built environment, particularly in the context of British housing policy for example, it has been influential in the shaping of "mixed communities" 
and "sustainable communities," through neighborhood regeneration during the 1990s and 2000s (Raco, 2007, 2009; Lees, 2014a, 2014b; Woodcraft and Smith, 2018). In a U.K. policy context, for example, the Sustainable Communities Plan of 2003 (ODPM, 2003) focused on 12 important requirements of sustainable communities, four of which related to "social dimensions" (Woodcraft, 2016; Woodcraft and Smith, 2018). These included strong leadership to respond to change; effective management and participation by local people, groups, and businesses in long-term stewardship of their community: a diverse, vibrant, and creative local culture, encouraging pride in the community and cohesion within it; and a "sense of place."

Since 2003, however, critics of the sustainable communities agenda have argued that rather than creating communities that are socially sustainable, in many instances (e.g., in major U.K. "estate regeneration" housing projects) they have in fact displaced people, diluted the social mix of communities, and undermined their social sustainability (Lees, 2014a). Moreover, the abandonment of specific sustainable communities policy by the U.K. coalition government in 2010, a renewed emphasis on estate regeneration, and the refocusing of planning policy towards "growth dependence," through the National Planning Policy Framework (NPPF) (DCLG, 2012), opened up new opportunities for homebuilders and developers to re-interpret what sustainable community means. More specifically, critics of this agenda also argue it has led to particular interpretations being assigned to social sustainability, which as a result, has also isolated and decoupled the concept from a broader and more integrated sustainability agenda in homebuilding (Woodcraft and Smith, 2018).

Homebuilders in the U.K. have therefore become the focus of continued attention as they seek not only to respond to changing national planning policies and the continued debate over housing supply, but also to react to continued business requirements and fulfil corporate responsibility requirements (Payne, Adams, and Watkins, 2008). Driven also by the influence of the Public Services (Social Value) Act 2012 (which requires the wider value of a project to be taken into account during request for tender), and a perceived "first mover" advantage (HCA/JLL, 2015), some U.K. homebuilders (and social housing providers) have therefore developed new assessment frameworks, which are designed to define and measure the social sustainability of new housing developments in a variety of specific contexts, including new build and estate regeneration (e.g., Bacon, Cochrane, and Woodcraft, 2012; Provan, Belotti, and Power, 2016; Caistor-Arendar et al., 2017). While a range of "ex ante" assessment tools such as BREEAM communities already exist and continue to be used to measure social sustainability as part of overall neighborhood sustainability primarily before development has begun (Sullivan, Rydin, and Buchanan, 2014; Callway, Dixon, and Nikolic, 2019), the new assessment frameworks are specifically designed for the measurement of social sustainability (or social value) of housing projects either after construction has begun or has been completed (ex post).

However, the use of such assessment frameworks raises questions not only over how the term social sustainability is being defined in the context of U.K. homebuilding, but the extent to which such frameworks are valid measures of 
social sustainability; what theoretical concepts the frameworks are anchored against; and what their strengths and weaknesses might be. Moreover, these questions need to be set in the wider context of the continued critique of U.K. homebuilding, especially in relation to estate regeneration, and the changing perspectives, roles, and responsibilities of homebuilders in relation to social sustainability (Lees, 2014a; Woodcraft, 2016).

This industry-led focus on social sustainability also follows a growing body of academic literature in which researchers have sought to define and measure social sustainability in a wider built environment context (Colantonio and Dixon, 2009; Shirazi and Keivani, 2017, 2018). However, it is clear that the new and emerging assessment frameworks are closely connected with (and developed from) a more specific literature and academic discourse in the built environment (Woodcraft, Hackett, and Caistor-Arendar, 2011; Woodcraft, 2012; Bacon, Cochrane, and Woodcraft, 2012). Studies have explored a variety of concepts and measures, but in particular they are linked by a common focus on: (1) ex post measures of social sustainability usually within an existing, well-established housing area; and (2) a neighborhood housing scale.

My aim in this paper is therefore to critically review the development of ex post assessment methods relating solely to social sustainability that are applicable to new housing developments at a neighborhood scale (particularly where a community already exists). To do this, the paper is presented in four parts and draws on U.K. and international literature throughout. First, I examine the reasons for the emergence of social sustainability in the U.K. homebuilding sector, and how the concept continues to be contested particularly within the context of housing-led U.K. regeneration policy and practice. Second, I trace the wider origins, definitions, and theoretical constructs of social sustainability in the built environment at a neighborhood scale. Third, I critically review assessment methods for social sustainability in housing development (focusing primarily on private sector homebuilding but with also some discussion of social housing), their theoretical underpinning, and their application in specific projects in the U.K. and elsewhere. Fourth, I critically review a new U.K. homebuilder social sustainability assessment framework (developed for Berkeley Group ${ }^{1}$ ) in the context of other emerging frameworks from, for example, Canada and Denmark. I conclude the paper by looking at the critical challenges and research questions about social sustainability that such frameworks raise, and how they might be improved and further developed.

\section{Social Sustainability: An Emerging and Contested Concept in U.K. Housing Development}

The origins of the recent interest and debate about social sustainability in U.K. homebuilding can be traced to the concept of "sustainable communities" developed by the U.K. Labour government in 2003. Sustainable communities were defined as (ODPM, 2005:1): “... places where people want to live and work now and in the future. They meet the diverse needs of existing and future residents, are sensitive to their environment, and contribute to a higher quality of life." 
In this, and related policy and practice guidance [e.g., Planning Policy Statement 1-Delivering Sustainable Communities (ODPM, 2005)], there was a particular emphasis on sustainable communities as being places in which employment, mixed housing, and social facilities were present and available to a range of socioeconomic groups, and which drew on previous thinking of idealist models of urbanism (Raco, 2007). The U.K. Labour government's sustainable communities' policy therefore also incorporated a strong emphasis on "mixed communities," which actively promoted changes to housing tenure and social mix in urban regeneration projects (Lees, 2014a).

However, although the concept of mixed communities continues to be actively promoted by the current U.K. Conservative government, albeit in a different guise, Labour's sustainable communities' policy has gradually been dismantled. The current U.K. government's approach to urban regeneration now places an emphasis on what it calls "community-led developments," but with strong local authority and private sector inputs, and a focus on "localist" solutions (Hall, 2015; DCLG, 2016). Moreover, this new deregulated environment has been underpinned by a new emphasis on growth-led planning (e.g., the introduction of the National Planning Policy Framework in 2012 suggests there is a presumption in favor of sustainable development).

For some commentators this change in emphasis presents a "discursive space" for re-interpreting the concept of sustainable communities and mixed communities (Woodcraft, 2016: Woodcraft and Smith, 2018). Indeed, an already deregulated policy agenda was also further loosened with the abolition of the Code for Sustainable Homes in 2015, which followed the Coalition-led government's Housing Standards Review (Greenwood, Congreve, and King, 2017). Woodcraft and Smith (2018) suggest that this has led to a fragmentation of the sustainability agenda and its re-interpretation by homebuilders as distinctive elements. Therefore, while environmental and economic sustainability are relatively easy to measure with available tools and metrics, social sustainability is open to interpretation and is "unclaimed territory," or as Woodcraft and Smith suggest (2018:74): " $\ldots$ a new space for architects, planners and developers to signify innovative practices and differentiate themselves in a highly competitive market." This growing emphasis on social sustainability also comes at a time when reshaped estate regeneration has become an important focus for current government housing policy in England. This, it is argued by the U.K. government (previously under David Cameron and subsequently under Theresa May), is a direct and appropriate response to the U.K.'s urgent housing problem, and it also resonates with other policies regarding the restructuring of large post-war housing estates in Europe (van Kempen, Dekker, Hall, and Tosics, 2005).

However, estate regeneration policy and homebuilders have for many years faced severe criticism from a number of quarters, particularly in London, with a particular focus on gentrification (Lees, 2014a; Watt and Minton, 2016). Lees (2014a), for example, talked about the severe direct and indirect displacement effects of new developments on existing council estates in London, such as Carpenters (Stratford), Ferrier (Woolwich), and Heygate and Aylesbury (Southwark) [see also Elmer and Dening (2016) and Flynn (2016)]. In such 
estates, under the guise of what Lees (2014a) refers to as "mixed communities" policy, there is evidence to suggest high levels of displacement through decanting of existing residents, and gentrification, as expensive housing prices typically keep lower income local people out of the market (Davidson and Lees, 2005). Continuing controversy over estate regeneration in England, therefore, raises profound questions about what is meant by "social sustainability" in housing-led regeneration projects. For Lees (2014a), the term, "social sustainability" has itself been used as rhetorical cover to mask much of the perceived state-led gentrification and "social cleansing" that she believes has been continuing under successive governments, particularly in London, since the late 1990s.

However, these critical perspectives overlook the importance of organizational and policy drivers that have influenced the recent focus on social sustainability by U.K. homebuilders. First, seen from the point of view of homebuilders themselves, there is a strong business rationale to engage with the wider corporate responsibility agenda, which includes social sustainability (Payne, Adams, and Watkins, 2008; Osmani and O'Reilly, 2009), which is also a point highlighted in the international literature on corporate sustainability reporting in the real estate industry (e.g., Laposa and Villupuram, 2010). Initially, engagement with the corporate responsibility process has been slow, but since 2007, the Next Generation Sustainability Index (supported by the Homes and Communities Agency (now the Homes Agency) has not only revealed improved sustainability performance for the top 25 U.K. homebuilders, but also an increasing focus by homebuilders on social sustainability and social impact (e.g., HCA/JLL, 2015, 2016).

Second, within the sphere of social housing provision, the recent introduction of the Public Services (Social Value) Act 2012, which came into effect in England and Wales in 2013, places a requirement on housing associations and other providers to consider social value when they procure services (CIH, 2015; Watson and Whitley, 2017). There has therefore been wider discussion and debate about the most appropriate tools and frameworks to measure social value (Florman, Klinger-Vidra, and Facada, 2016). This has also been underpinned by recent built environment practice guidance, which highlights the societal and business benefits of directly measuring social value (Supply Chain Sustainability School, 2017; UKGBC, 2018).

Third, the debate over the measurement of social sustainability (and social value) has come at a time when other U.K. government-funded research has highlighted the importance of measuring the impacts and outputs from the urban regeneration policy (Tyler, Warnock, Provins, and Lanz, 2013). This evaluation of urban regeneration policy has emphasized the importance of homes, communities, and the environment as a key focus of measuring outcomes (or the measures of social, economic, and environmental characteristics of areas or groups of people) (DCLG, 2010a, 2010b; Tyler, Warnock, Provins, and Lanz, 2013). Moreover, others have found that good urban design can bring multiple added social and environmental values to developments, which in combination positively affect economic value (Carmona, Tiesdell, Heath, and Oc, 2010; Nase, Berry, and Adair, 2015; RICS, 2016). 
In response to these drivers, there has been a growing focus on social sustainability and social impact measurement in recent years, particularly from homebuilders such as Berkeley Group, Countryside Properties, and Taylor Woodrow (Bacon, Cochrane, and Woodcraft, 2012; Berkeley Group, 2014; HCA/JLL, 2016; CaistorArendar et al., 2017) but also from social housing providers. In the next two sections, the development of the concept of the social sustainability of housing at neighborhood level, and the emergence of assessment methods for measuring the social sustainability of housing are examined in detail.

\section{Social Sustainability in the Built Environment: Origins, Definitions, and Theory}

Over the last 20 years, the concept of social sustainability has gained an increased focus in academic and policy discourse across a wide range of disciplines from science and engineering through to social science and the humanities (Woodcraft, 2012; Shirazi and Keivani, 2017). However, although social sustainability is a key element within the overarching concept of sustainable development in the Bruntdland report (WCED, 1987), it was not until the late 1990s that social issues became a focus for discussion and debate within the sustainability agenda (Hediger, 2000; Colantonio, 2009). Moreover, as Colantonio (2009a) notes, the concept of social sustainability has been under-theorized or often over-simplified in existing theory.

In the context of built environment literature, Polese and Stren (2000, pp. 5-16) offered one of the earliest definitions of social sustainability at an urban scale as being: "Development (and/or growth) that is compatible with harmonious evolution of civil society, fostering an environment conducive to the compatible cohabitation of culturally and socially diverse groups while at the same time encouraging social integration, with improvements in the quality of life for all segments of the population." As Colantonio (2009b) points out, this definition particularly emphasizes the economics (development) and social (civil society, cultural diversity and social integration) dimensions of sustainability, and highlights the potential tensions and trade-offs between development and social integration.

However, this is just one of the many definitions of social sustainability within the built environment literature. For example, Shirazi and Keivani (2017), provide a detailed analysis of some 29 research publications that offer contrasting and differing conceptualizations of social sustainability across varying scales (local to regional). These were then categorized as approaches in the following groups: cultural development and diversity, procedural quality (i.e., social sustainability as a process rather than a condition), practical tool for urban policy, wellbeing, equity and democracy, capacity building, and physical/non-physical aggregation.

In the context of housing in the built environment, the physical/non-physical aggregation category is particularly relevant, because it emphasizes the strong synergy between what might be termed "soft" social infrastructure and "hard" community infrastructure (Colantonio and Dixon, 2011; Shirazi and Keivani, 
2017). For example, Cuthill (2010) in a study of South East Queensland (Australia) suggests that social sustainability comprises four main elements. First, social capital, which can be defined as (World Bank, 1998:1) "the institutions, the relationships, the attitudes and values that govern interactions among people and contribute to economic and social development." Second, social justice and equity, or the moral and ethical foundations underpinning social sustainability. Third, engaged governance, or the idea that all stakeholders including citizens from all spectrums of society should be involved in democratic decision-making and planning processes. Finally, Cuthill $(2003,2010)$ also incorporates soft social infrastructure, which includes community services, and the capacity building of groups needed to work together to create a sustainable community. In contrast, hard social infrastructure comprises physical assets in the built environment, such as transport and urban services (e.g., health and education) needed to provide support for communities.

This distinction between soft and hard infrastructure has also carried over into much of the academic discourse on social sustainability at the neighborhood level. In this sense, a neighborhood is generally defined as an area in a city with connected areas of blocks of buildings (Zheng et al., 2017), and is important in the overall context of sustainability in the built environment because regeneration and redevelopment often takes place at this scale (Sharifi and Murayama, 2013).

Research at the neighborhood level in the built environment (especially in relation to housing) has therefore frequently focused on the relation between urban form and density and social sustainability (Chiu, 2005; Bramley et al., 2009; Raman, 2010). For example, Bramley et al. (2009) suggested that social sustainability comprises two main dimensions. First, social equity, with particular reference to services and opportunities (e.g., shops, schools, health centers, transport jobs, and housing); and second, sustainability of community, including pride and attachment to a neighborhood; social interaction within the neighborhood; safety and security; and perceived quality of the environment and participation in collective group/ civic activities. This research also recognizes that sustainability of community can also be interpreted as quality of life, which could in turn include concepts of health and wellbeing (or social and cultural life).

Linked to this work, Dempsey, Bramley, Power, and Brown (2011) developed a valuable categorization of non-physical (e.g., health, quality of life, and social inclusion) and physical factors (e.g., urbanity, accessibility, and attractive public realm) based on an extensive literature review, which are closely related to some of the soft and hard infrastructure concepts developed by Cuthill (2003). The implication of this conceptualization in theory and policy relating to urban design is not only that concepts such as social cohesion, social capital, and social inclusion and living in high quality urban living environments are positive and desirable social goods, but also that the social order promoted by this is positively correlated with health, happiness, and good quality of life.

This literature on social sustainability also helped inform work by Woodcraft, Hackett, and Caistor-Arendar (2011), which was commissioned by the U.K. Homes and Communities Agency. Again, drawing on literature in the field, these 
authors suggested there were four main elements of social sustainability that are essential in building new communities. First, amenities and infrastructure, or the physical amenities and social infrastructure needed to be in place in the early life of a new community, with an emphasis on schools, social spaces, transport, and community services. Second, social and cultural life, relating to shared spaces, collective activities, and the social architecture needed to develop and foster networks, belonging, and local identity. Third, voice and influence, or the governance structures needed to help residents shape and influence local decisionmaking and stewardship. Fourth, space to grow, or the concept that places need to have an inbuilt capacity for flexible planning, housing, infrastructure, and services that can adapt over time.

Building on this work, Social Life (a social enterprise) and University of Reading (Bacon, Cochrane, and Woodcraft, 2012; Dixon and Woodcraft, 2013) developed a social sustainability assessment framework for Berkeley Group, a major U.K. homebuilder. Social sustainability from a homebuilder's perspective was defined as being (Bacon, Cochrane, and Woodcraft, 2012, p. 9) as “... about people's quality of life, now and in the future. It describes the extent to which a neighbourhood supports individual and collective well-being. Social sustainability combines design of the physical environment with a focus on how the people who live in and use a space relate to each other and function as a community. It is enhanced by development which provides the right infrastructure to support a strong social and cultural life, opportunities for people to get involved, and scope for the place and the community to evolve."

This definition places a strong focus on emphasizing both the physical and nonphysical or hard and soft aspects of social sustainability from the literature, and it also formed the basis for an assessment framework and set of metrics for measuring social sustainability, which has been applied in a number of the Berkeley Group's developments (Bacon, Cochrane, and Woodcraft, 2012), and in an adapted form for Countryside Properties (Caistor-Arendar et al., 2017).

As stated earlier, capital theory has played an important role in shaping social sustainability discourse in the built environment, especially in relation to the consideration of social capital (Cuthill, 2003, 2010). Moreover, social capital, or the social structures and networks upon which people depend, is an implicit element within Bacon, Cochrane, and Woodcraft's (2012) definition of social sustainability for a U.K. homebuilder. Others have argued, however, that within the overall context of social sustainability in housing (particularly in the social housing sector), social value should also be considered as being important (Bichard, 2016; Provan, Belotti, and Power, 2016; Watson, Evans, Karvonen, and Whitley, 2016). Although related to the notion of social capital, some view social value as a value-based (or monetized) concept connected to the softer impacts of organizations and programs. Wood and Deighton (2016, p. 20), for example, define social value as: "The wider non-financial impacts of programmes, organisations and interventions, including the wellbeing of individuals and communities, social capital and the environment. These are typically described as 'soft' outcomes, mainly because they are difficult to quantify and measure." 
Despite the difficulties of measuring social value objectively, a range of social impact measures have been developed, focusing on social value outcomes at different scales. In a built environment context, debate has crystallized around the use of social return on investment (SROI), which has been used to assess social value, not only in individual buildings (Watson, Evans, Karvonen, and Whitley, 2016), but also in neighborhood scale urban regeneration projects involving housing associations or specialist social housing providers (e.g., Bichard, 2016; Provan, Belotti, and Power, 2016; Vine et al., 2017; Higham, Barlow, Bichard, and Richards, 2018). However, in housing, these techniques have been applied mainly in the context of social housing providers, and not within the private homebuilding sector, although in a recent study of new private housing, Redrow (2018) calculated social value using wellbeing measures as a monetary tool. Furthermore, the concept of social value implies a valuation or monetization of the impacts of particular housing-led activities, which is a key distinguishing feature from the wider social sustainability literature described above examining current and future sustainability (UKGBC, 2019). In the rest of this paper, the focus is therefore on social sustainability in housing, and not on social value.

\section{Social Sustainability Assessment in Housing Development: Methods and Applications}

Importantly, the work discussed above acknowledges that the practical and operational aspects of social sustainability are often not well explored, clearly defined or well-integrated in the policy and practice of urban planning, regeneration, and housing (Colantonio and Dixon, 2011; Vallance, Perkins, and Dixon, 2011; Weingaertner and Moberg, 2014). However, a number of empirical studies of social sustainability have focused on housing at a neighborhood scale in the U.K. and internationally. These comprise two main types of study: (1) urban form and density studies in existing housing; and (2) assessment frameworks for new housing projects. In this section, I discuss these two types of study and the emergence of recent international research in the field.

\section{Urban Form and Density Studies in Existing Housing}

These studies have focused on attempting to establish a relationship between the nature of the physical urban environment (in terms of its morphology, for example, in terms of urban form and density) and the level of social sustainability (based on key measures of soft elements). For example, Chiu (2003), in a study of housing in a central neighborhood of Hong Kong, developed a set of indicators to measure social sustainability. These comprised (1) livability indicatorsinternal housing conditions and external residential quality; and (2) equity in housing distribution and consumption-affordability (private housing); accessibility to housing markets; inadequately housed households; accessibility to public housing; and adequacy of government subsidy in housing. Using a combination of published data and interviews with residents, the study attempted to measure the extent of social sustainability. 
Bramley et al. (2009) used measures of physical and non-physical social sustainability to try to establish a link between density and the extent of social sustainability in a study of 15 neighborhoods in five British cities. Using resident surveys to assess perceptions of social sustainability and MCA analysis to measure spatial structures and compactness, they showed (through statistical testing) that broadly speaking, social outcomes relating to attachment, satisfaction, safety, and the environment are more positive at lower densities and in less central locations, while outcomes related to the use of local services display the opposite.

Other studies have found varying degrees of a relationship between the physical urban environment and measures of social sustainability (e.g., Abed, 2017; Ancell and Thompson-Fawcett, 2008; Raman, 2010; Yoo and Lee, 2016). Nevertheless, all have used resident surveys to examine perceptions, often combined with formal measures of urban morphology, and statistical testing to examine the strength of these relationships with varying degrees of success.

\section{Assessment Frameworks for New Housing Projects}

More recently, work commissioned by Berkeley Group in the U.K. (Bacon, Cochrane, and Woodcraft, 2012) scoped out and drew on this previous research as background and context for the development of a more detailed assessment of social sustainability for a private sector homebuilder. The focus of the Berkeley Group framework, and the starting point for the measurement of social sustainability, therefore was on the aspects of community strength and quality of life that a homebuilder could reasonably be held directly accountable for (or could influence) through relationships with public agencies (Bacon, Cochrane, and Woodcraft, 2012; Dixon and Woodcraft, 2013). The framework therefore incorporated three main elements (Bacon, Cochrane, and Woodcraft, 2012; Berkeley, 2014) as shown in Exhibit 1, and based on the definition of social sustainability provided above.

To operationalize the framework, the three different dimensions incorporated 13 different indicators (Exhibit 1). Each indicator is informed by a number of different questions, drawn primarily from national datasets or industry-standard assessment tools. In total, 45 different questions are used to inform the indicators. For example, in relation to wellbeing, the following questions can be used to compare responses on wellbeing within the housing project with comparable places in a much larger national data set: (1) Have you recently felt that you were playing a useful part in things?; (2) Have you been feeling reasonably happy?; (2) How dissatisfied or satisfied are you with life overall?; and (4) Overall, how satisfied or dissatisfied are you with your local area as a place to live?

The results of household surveys in the new housing project are then compared with responses to the same questions in three large-scale national surveys: (1) Understanding Society, the U.K.'s largest, longitudinal household panel survey with 40,000 participating households (2011-2012); (2) Community Life, an annual survey based on approximately 6,000 face-to-face interviews (2012-2013); and, (3) the British Crime Survey, an annual survey of 35,000 people (20112012). The indicators from the amenities and infrastructure dimension of the 
Exh ib it 1 | Berkeley Group Social Sustainability Indicators

\begin{tabular}{|c|c|c|c|}
\hline $\begin{array}{l}\text { Component of Social } \\
\text { Sustainability }\end{array}$ & Focus & Indicators & Benchmark Data \\
\hline $\begin{array}{l}\text { Amenities and } \\
\text { infrastructure }\end{array}$ & $\begin{array}{l}\text { Past and planned attempts to } \\
\text { lay the foundations for a } \\
\text { thriving community through } \\
\text { housing mix, public realm, } \\
\text { landscaping, transport } \\
\text { connections, and community } \\
\text { infrastructure. }\end{array}$ & $\begin{array}{l}\text { Community space; } \\
\text { transport links; } \\
\text { distinctive character; } \\
\text { local integration; } \\
\text { street layout; } \\
\text { adaptable space. }\end{array}$ & $\begin{array}{l}\text { Based on structure and } \\
\text { scoring system of the } \\
\text { CABE Building for Life } \\
\text { survey. }\end{array}$ \\
\hline Social and cultural life & $\begin{array}{l}\text { Illustrates the present, how } \\
\text { people experience the } \\
\text { development and how this } \\
\text { contributes to their quality of } \\
\text { life, perceptions of safety, } \\
\text { feelings of belonging and } \\
\text { interaction with neighbors. }\end{array}$ & $\begin{array}{l}\text { Links with neighbors; } \\
\text { wellbeing; feelings } \\
\text { of safety; local } \\
\text { facilities. }\end{array}$ & $\begin{array}{l}\text { Understanding } \\
\text { Society; } \\
\text { Community Life } \\
\text { British Crime Survey. }\end{array}$ \\
\hline Voice and influence & $\begin{array}{l}\text { Residents' potential to shape } \\
\text { their future through } \\
\text { opportunities to engage and } \\
\text { influence the built } \\
\text { environment and shape their } \\
\text { everyday lives. }\end{array}$ & $\begin{array}{l}\text { Willingness to act; } \\
\text { ability to influence. }\end{array}$ & $\begin{array}{l}\text { Understanding } \\
\text { Society: } \\
\text { Community Life } \\
\text { British Crime Survey. }\end{array}$ \\
\hline
\end{tabular}

Note: The table is adapted from Bacon, Cochrane, and Woodcraft (2012).

framework were created by selecting questions from the Building for Life20 assessment tool, an industry standard that is endorsed by the U.K. government; from the Public Transport Accessibility Level (PTAL) tool (an assessment used widely in London); and from additional sources of secondary data about residents' travel habits. Additionally, a number of questions were created for this dimension where appropriate questions did not exist.

The benchmarking method uses the Office for National Statistics' Output Area Classification (OAC) and the Index of Multiple Deprivation (IMD) classifications to identify the average responses for areas that share the same OAC social profile and IMD ranking. This approach enables comparison between the average responses of people living in a development, to the benchmark, which are the average responses of people with a similar social profile in comparable areas. ${ }^{2} \mathrm{~A}$ RAG (red-amber-green) rating system is used to provide a simple graphic representation of the results, where green indicates a positive result that is higher or better than would be expected; amber a satisfactory result in line with the benchmark for a comparable place; and red a negative response, lower than would be expected. The RAG rating system was adopted to present the results in a form that is practical and meaningful for different audiences, and to enable presentation 


\section{Exhib it 2 | RAG for Kidbrooke Village}

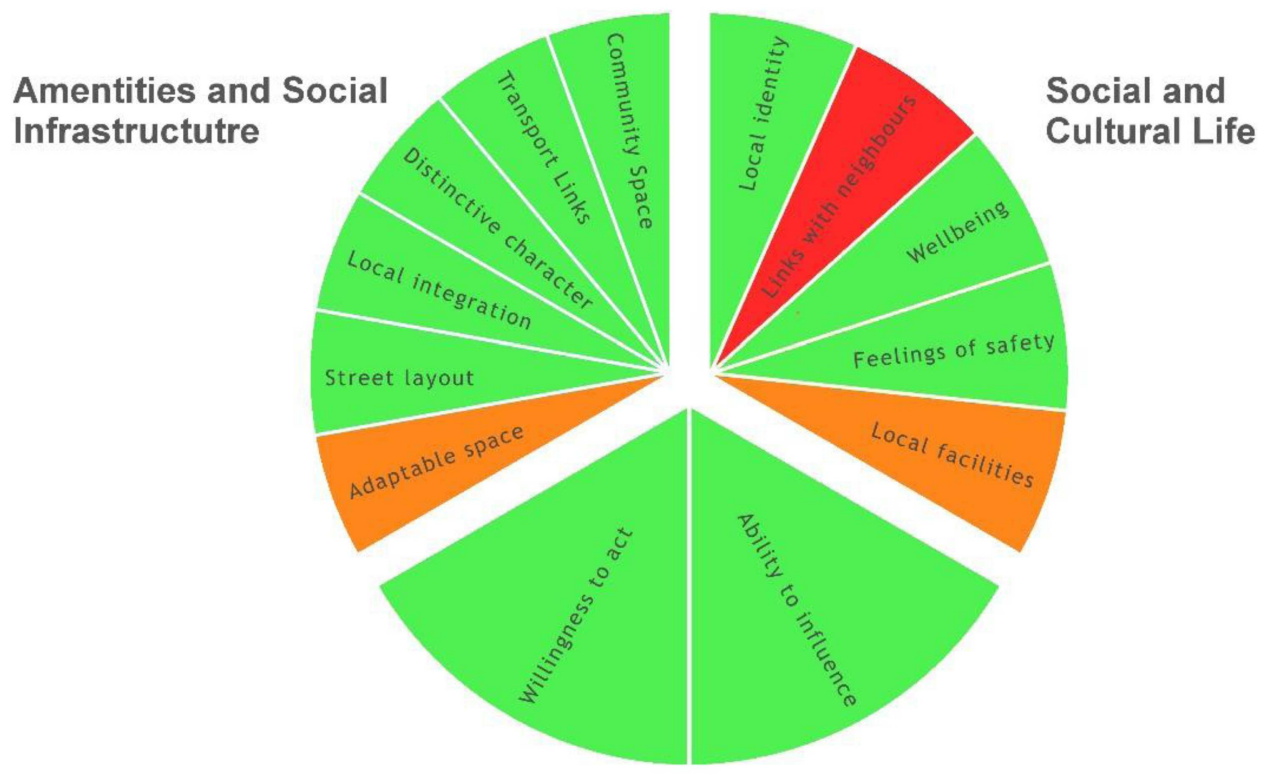

Voice and Influence

Note: The source is Bacon, Cochrane, and Woodcraft (2012).

of a range of responses rather than a single social sustainability score (Bacon, Cochrane, and Woodcraft, 2012).

An example is given in Exhibit 2. This shows Kidbrooke Village in the Royal Borough of Greenwich, South East London. The development is a $£ 1$ billion regeneration project which, over the next 15-20 years, will create a new suburban community on the site of the former Ferrier Estate. It is currently one of the largest regeneration projects in the U.K. and has been planned to provide a new mixed-tenure, mixed-used community with 4,800 homes, schools, shops, health facilities, restaurants, offices, community facilities, and open spaces.

A social sustainability assessment was undertaken at the beginning of 2013. An independent site survey was also carried out, and 125 residents (24\% of occupied households) were interviewed using random sampling and tenure-based quotas. Exhibit 2 shows the resulting RAG ratings (derived from statistical comparisons with national benchmarks) against the 13 indicators in the framework. Exhibit 2 shows that 10 of the 13 indicators are positive for Kidbrooke Village, which means that residents' experiences were above the benchmarks for comparable places. Two of the indicators, adaptable space and local facilities, are rated as satisfactory, which means a comparable experience to the benchmarks. One of the indicators, links with neighbors, is red, meaning that the residents reported experiences below the benchmarks for comparable places (Dixon and Woodcraft, 2013). 
Besides Kidbrooke Village, the framework has been applied in a number of Berkeley Group developments in London and south east England, including Empire Square (regeneration project); the Hamptons (suburban dwellings); Imperial Wharf (urban); Knowle Village (rural/semi-rural); Beaufort Park (area regeneration); and more recently in Saffron Square (urban); Woodberry Down (estate regeneration); and Royal Arsenal (urban) [see Bacon, Cochrane, and Woodcraft (2012); Woodcraft and Dixon (2013), and Berkeley Group (2015a, 2016) for a full discussion of results].

However, the Berkeley Group studies have focused exclusively on assessing the social sustainability of the residents of the new development and did not attempt to measure the social sustainability perceptions of neighboring residents, or the potential impacts on them of the new housing project [or indeed on existing residents directly affected by the new development, for example, in terms of displacement or dilution (social mixing)].

More recently, Countryside Properties, another major U.K. homebuilder, has adapted the same framework to assess social sustainability in a major estate regeneration project in London (Acton Gardens) (Caistor-Arendar et al., 2017; Dixon et al., 2019). In this case, the assessment of social sustainability focused not only on the new residents taking up occupation, but also the neighboring and existing residents in the surrounding area. In parallel, the work was supported by a survey of residents across the estate and neighboring areas as to their perceptions and attitudes towards the estate regeneration.

\section{Recent International Research}

Since the Berkeley Group framework was developed, several other studies have emerged that attempt to develop measures for the social sustainability of housing in different contexts internationally. Shirazi and Keivani (2018), for example, have developed a triad system for measuring existing residential neighborhoods. Their model focuses on soft infrastructure or non-physical factors (neighboring), hard infrastructure or physical factors (neighborhood), and the population profile or demographics of the neighborhood (neighbor), and while (to date) the framework is not yet operationalized, their review includes a discussion of what data would be required to measure social sustainability (including survey work and census data).

Severson and de Vos (2018) have also developed a measurement framework for assessing social sustainability in new social and affordable housing for Capital Region Housing projects in Alberta, Canada, which builds on the Berkeley Group work. The authors suggest that four key dimensions of social sustainability are important: housing standards, non-shelter needs, community integration and social inclusion, and capacity building and resilience. Again, the data requirements are considerable: 49 measures for 15 different indicators across the four dimensions. Their framework focuses on basic housing needs, as well as the higher order needs catered for in the Berkeley Group framework, but the focus is very much on social and affordable housing. Crucially, Severson and de Vos (2018) also highlight the 
Exh ibit 3 | Key Social Sustainability Measures

\begin{tabular}{lll}
\hline Dimension & Indicator & Key Measure \\
\hline Housing Standards & Affordable & Capacity to Support Self/Family \\
$\begin{array}{l}\text { Non-Shelter Needs } \\
\text { Community Integration and }\end{array}$ & $\begin{array}{l}\text { Social Inclusion } \\
\text { Social Inclusion }\end{array}$ & $\begin{array}{l}\text { Change in ability to support self \& family } \\
\text { Feeling of belonging }\end{array}$ \\
$\begin{array}{l}\text { Capacity Building and } \\
\text { Resiliency }\end{array}$ & Education and Capacity Building & $\begin{array}{l}\text { Number of partnerships or MOUs } \\
\text { between housing provider and } \\
\text { community partner agencies }\end{array}$ \\
\hline
\end{tabular}

Note: The source is Severson and De Vos (2018).

importance of inter- and intra-generational equity as a key feature and point to the importance of grounding social sustainability in the improvement of quality of life and not simply its measurement. This means measuring social sustainability biennially is important, so that a longitudinal picture of social sustainability is built up. Moreover, they also point out that there are four key measures that capture the goal of each of the four priorities and can act as high-level indicators (Exhibit 3).

Finally, Stender and Walter (2018) used a framework based on accessibility, social cohesion, and participatory processes to analyze two social housing estates in Denmark. They also highlight the dangers of using social sustainability as a means to an economic end rather than an end in itself, and that robust methods are needed to overcome accusations of "social washing" (the social equivalent of "green washing"). Building on the Berkeley Group work and the social sustainability framework described above, their research highlighted the need to integrate such measures of social sustainability with assessment tools such as the Danish DGNB certification system. The first Danish version of the German DGNB certification was launched in the spring of 2012, and is a result of a large voluntary effort from experts in the field and organizations related to the building industry. The German criteria have been adapted and reviewed to fit the Danish standards, law, and in practice (DGNB, 2019). The researchers compared the ex post social sustainability of two new housing estates with the original DGNB assessment(s). The latter has a sociocultural and functional quality measure for social sustainability, which includes social and functional diversity, social and commercial infrastructure, safety, urban life, noise reduction, supply of recreational areas, accessibility, flexibility, urban integration, urban form, and usage of existing structure and art in public places. Stender and Walter suggested that the DGNB assessment procedure could be modified to also take into account initiatives that preserve and integrate existing social networks; janitorial staff who act as operators of the assets as well as facilitators for social networks and digital platforms; and to also incorporate better ways of measuring overall integration in social housing. 


\section{Exh ib it 4 | Conceptualization of Social Sustainability in New Neighborhood Scale Housing} Projects
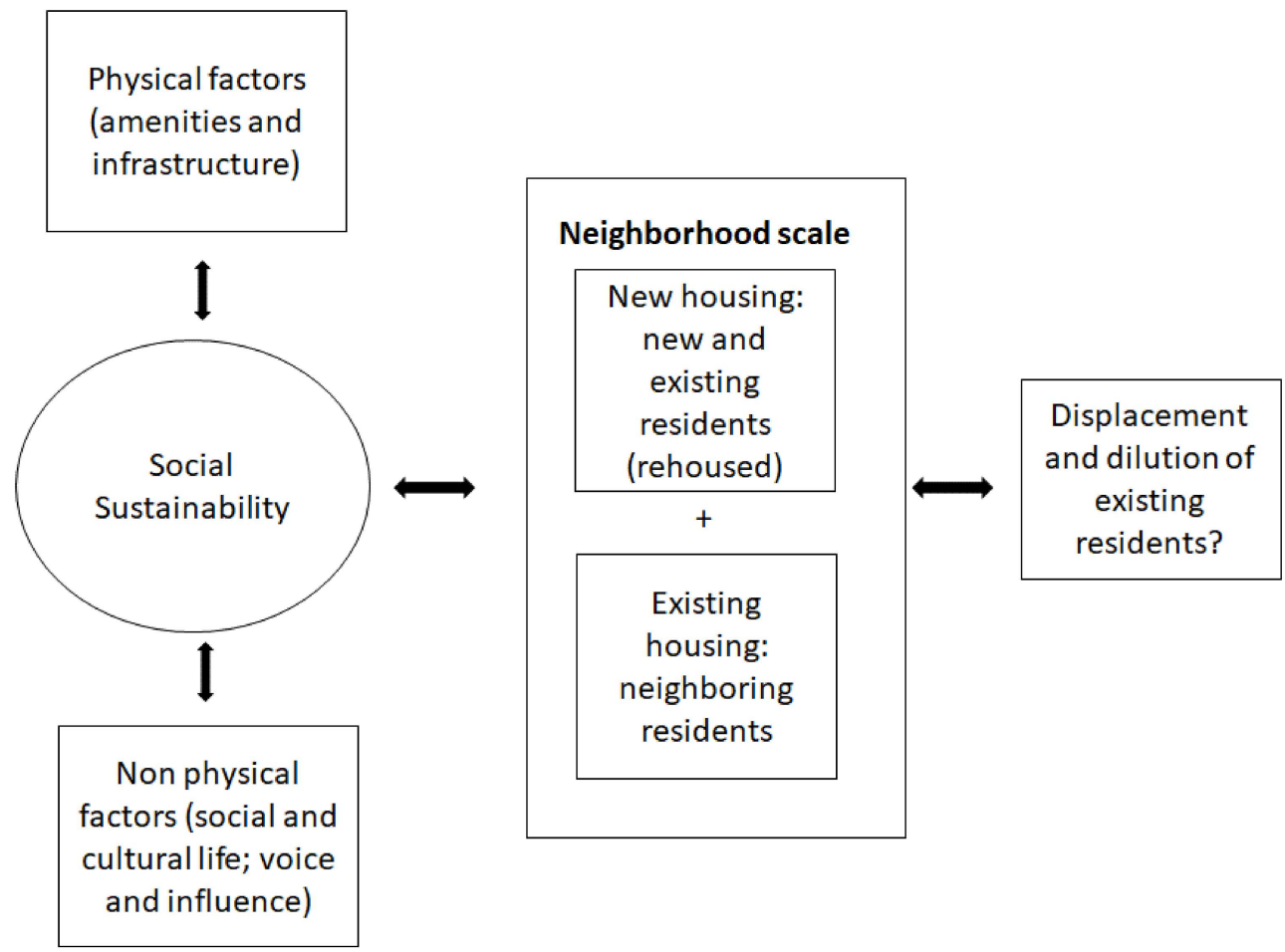

\section{Discussion and Review}

\section{Social Sustainability: Benchmarking and Availability of Data}

The development of a social sustainability assessment framework for new housing projects raises a number of important issues and challenges. It is therefore important to understand the conceptualization of the research problem. Adopting the physical/non-physical categorization of social sustainability, which is at the heart of much of the relevant literature in the field, in Exhibit 4 I summarize the key elements that should be understood in terms of measuring social sustainability in new housing development where there is an existing community. This conceptualization builds on the work developed for the Berkeley Group (Bacon, Cochrane, and Woodcraft, 2012). However, it stresses the importance of assessing the impact of new housing projects on residents who may be displaced as the estate regeneration continues (a process often referred to in relevant literature as gentrification), and also the neighboring residents who, although not displaced, may feel the community has been impacted and the local environment changed, for better or for worse (Lees, 2014a, 2014b; Bouzarowski, Franowski, and Herrero, 2018). This framework therefore provides a major challenge for homebuilders to 
go beyond the aim of simply examining the impact of development on the new residents moving into the development, but to also focus on the social impacts for the existing community (Dixon et al., 2019).

It should be noted that the starting point for the Berkeley Group framework is to incorporate those elements of social sustainability that a homebuilder could influence, and so excludes such elements as health and social equity and is relatively limited in its focus (Bacon, Cochrane, and Woodcraft, 2012). In other words, the definition of social sustainability on which the framework is anchored is very specific and is linked to those elements for which a homebuilder could directly be accountable, or could influence through partnerships with public agencies. There may also be tensions between the outcomes of the social dimension and economic and environmental sustainability that need to be monitored, and for developers and homebuilders to avoid and overcome social washing accusations (Severson and de Vos, 2018; Stender and Walter, 2018). It is therefore a particular perspective on social sustainability that is highly mediated and relies on the selective inclusion of policy goals and professional practices to make it operational (Woodcraft, 2016). Nevertheless, the Berkeley Group framework does seem to offer the potential for homebuilders and local authorities to engage with residents directly in assessing social sustainability in a pragmatic, comparative, and measurable way, provided it is adapted and improved to include an assessment of displacement, and examines the impacts on the existing community explicitly and directly.

The Berkeley Group assessment framework has the advantage of offering a way of benchmarking projects internally and against comparable places using large census datasets. This seems to be a distinctive feature of the framework in comparison with, for example, recent frameworks highlighted by other authors in different contexts (see, for example, Stender and Walter, 2018). The Berkeley Group framework (and indeed other neighborhood assessment frameworks) also offers the advantage of measuring social sustainability not as a monetized rate of return (in contrast to the SROI) but by measuring the perceptions of residents directly. Indeed, as Severson and de Vos (2018) also point out, SROI is a single point value and does not examine current and future social sustainability per se. This is an important distinction because there has been evidence of the term "social sustainability" being "conflated" and confused with social value in some of the recent literature (Serin, Kenny, White, and Samuel, 2018; UKGBC, 2018). Yet the two terms are distinct and measurable concepts: with social value implying monetization and social sustainability, an indicator-based assessment (UKGBC, 2019).

Nonetheless one of the major practical challenges in constructing such a framework is also in combining the different types of data that underpin each indicator (Bacon, Cochrane, and Woodcraft, 2012; Woodcraft, 2016). In the Berkeley Group framework studies, data were selected to contribute different insights and perspectives to the framework, based on the available national datasets. The site survey work in the Berkeley Group case study sites focused on predicting the likely outcomes for residents, based on the well-established assumptions and experience of urban design practitioners, which is that good 
design and provision of community facilities will have a positive impact on outcomes for residents. The residents' surveys also attempted to measure what happens in communities when an estate is regenerated, for example. Also, the data included in the social and cultural life dimension is used to investigate how people feel about their neighborhood, their neighbors, and their own well-being. Finally, the residents' survey also attempted to look ahead to capture data about whether residents are willing and able to have a say in shaping the future of their local area (voice and influence).

\section{Improving and Developing Existing Assessment Frameworks for New Housing}

The discussion above raises three important issues for developing the framework. First, a key criticism of the use of social sustainability in U.K. mixed community policy has been that estate regeneration has actually undermined existing communities through displacement and enforced social mixing (see above). There is evidence to suggest that this has been a problem in a number of major London estate regeneration projects (Lees, 2014a; Watt and Minton, 2016). Overlooking this within a social sustainability assessment of new housing projects risks underplaying the importance of long-term social capital in a community. It is therefore important that displacement of residents (and dilution) is explicitly measured and acknowledged if such studies are to gain credibility (Exhibit 4). This is also a point raised by Bouzarowski, Franowski, and Herrero (2018) in relation to Gdansk in Poland and the low carbon gentrification (or renoviction) of a major neighborhood energy renovation program.

The transparent reporting of displacement is therefore essential. Although it is difficult to construct an explicit measure for this in the existing framework, not least because of the difficulties of benchmarking against other developments, reporting on raw numbers (where data availability permits) is possible. In Acton Gardens, for example, the estate regeneration program has a "right to remain" policy in place, which means that social housing tenants with secure tenancies who need to move as part of the regeneration program are offered the choice of moving to a new home being built on the South Acton estate, or an alternative Ealing Council property outside the estate (Dixon et al., 2019). Some 62\% of secure Ealing Council tenants have opted to move into a new L\&Q property within Acton Gardens to date. However, this does not include existing Ealing council leaseholders who have opted to buy a shared equity property with L\&Q, or residents who moved as part of the early regeneration (and for which data are currently unavailable). The number of residents choosing to remain living in South Acton has also increased in the past two years (to 2017), and 360 leaseholders have been offered the option of either owning a new property on the estate, through a shared equity lease, or being offered full market value for their current property with an additional 10\% compensation (Mayor of London, 2016). It will be important to monitor and report on displacement of residents alongside the indicators in the framework. Second, a framework for measuring social sustainability in new housing projects should also be able to track and monitor 
social sustainability periodically over time (e.g., every two to three years). Detailed interviewing is time-consuming and costly, however, and of course the more frequent the surveys, the higher the costs. Longitudinal tracking of social sustainability in this way does, nonetheless, enable the trajectory of social sustainability to be monitored and assessed over time. Indeed, the framework suggested by Severson and de Vos (2018) for social and affordable housing also places a strong emphasis on longitudinal, biennial measurement.

Third, this process of monitoring and evaluation also presupposes that reflexivity is embedded in the design process and that the homebuilders will use the results to reconfigure practice and design during the development process. Encouragingly, for example, Acton Gardens LLP (the development partnership that includes the homebuilder Countryside Properties) has made public commitments to respond to the recent research conducted, and highlighted four main areas they will act on: supporting residents in new housing to help them settle in the neighborhood; ensuring that existing residents of the South Acton Estate fully understand the rehousing process; accommodating local organizations offering important support services to the community; and recognizing the value that residents place on their relationships with friends and neighbors in the area (Dixon et al., 2019). The efforts to improve information provision and engagement with residents (e.g., in relation to phasing) has also increased because of the research findings: the community board is now larger and more diverse, and there are more resident forums and housing surgeries for residents. There is also due to be a new assessment of social sustainability published for Acton Gardens in 2019 in order to track and monitor progress longitudinally (Social Life, 2019).

\section{Conclusion}

The development of a recent U.K. social sustainability assessment frameworks for new housing projects builds on other social sustainability studies at the neighborhood level in the built environment, which have adopted an ex post focus. This comes at a time when a mixed communities policy in the U.K., and the concept of social sustainability itself, face growing criticisms not only related to the motives and intentions of homebuilders, but also the fact that social sustainability discourse itself is highly mediated and relies on the selective inclusion of particular elements by U.K. homebuilders. Ultimately such assessment frameworks are useful tools but require further development to assess social sustainability more objectively through: (1) a focus on both new and existing residents in the overall neighborhood when new housing projects impact existing communities (e.g., in a major estate regeneration); (2) an explicit consideration of displacement and social mix both before and after the new housing development; and (3) the long-term monitoring of social sustainability through continuing regular assessment. This is also important to consider in the light of new and emerging research (albeit in different housing contexts) from, for example, Denmark and Canada. 


\section{Endnotes}

1 This paper provides a critical review of relevant frameworks. For full results, the reader is referred to the relevant reports and publications included in the references, including those by the Berkeley Group.

2 To test whether responses from residents were different from the comparable area, a $z$ test for difference in proportions is carried out, with the survey questions as dependent variables (specifically the percentage answering positively to each question), and whether respondents were residents, or part of national or comparable place groups, as the independent variable. For each level of comparison, analysis of national and comparable place groups was carried out, selecting only those individuals that were members of the required comparison group.

\section{References}

Abed, R. Assessment of Social Sustainability: A Comparative Analysis. Proceedings of the Institution of Civil Engineers-Urban Design and Planning, 2017, 170:2, 72-82.

Ancell, S. and M. Thompson-Fawcett. The Social Sustainability of Medium Density Housing: A Conceptual Model and Christchurch Case Study. Housing Studies, 2008, 23: $3,423-42$.

Bacon, N, D. Cochrane, and S. Woodcraft. Creating Strong Communities: How to Measure the Social Sustainability of New Housing Developments. London: The Berkeley Group. Accessed May 2017 at: https://www.berkeleygroup.co.uk/media/pdf/7/8/berkeleyreports-and-opinions-social-sustainability-reports-creating-strong-communities-partone.pdf, 2012.

Berkeley Group. Creating Successful Places: A Toolkit. Berkeley Group: London. Accessed March 2018 at: https://www.berkeleygroup.co.uk/sustainability/social-sustainability/ creating-successful-places, 2014.

—. Woodberry Down Social Sustainability Report. Berkeley Group London. Accessed March 2018 at: https://www.berkeleygroup.co.uk/sustainability/social-sustainability/ creating-successful-places, 2015a.

—. Royal Arsenal Social Sustainability Report. Berkeley Group London. Accessed March 2018 at: https://www.berkeleygroup.co.uk/sustainability/social-sustainability/ creating-successful-places, $2015 \mathrm{~b}$.

—. Saffron Square Social Sustainability Report. Berkeley Group London. Accessed March 2018 at: https://www.berkeleygroup.co.uk/sustainability/social-sustainability/ creating-successful-places, 2016.

Bichard, E. Sustainable Return on Investment: Towards a Method of Valuing Social and Environmental Change in the Built Environment. Proceedings of the 2nd Annual International Conference on Social Sciences, 2016, 2, 866-74.

Bouzarovski, S., J. Franowski, and S. Herrero. Low Carbon Gentrification: When Climate Change Encounters Residential Displacement. International Journal of Urban and Regional Research, 2018, 42:5, 845-63.

Bramley, G., N Dempsey, S. Power, C. Brown, and D. Watkins. Social Sustainability and Urban Form: Evidence from Five British Cities. Environment and Planning A, 2009, 41:9, $2125-42$. 
Bramley, G. and D. Watkins. Housebuilding, Demographic Change and Affordability as Outcomes of Local Planning Decisions: Exploring Interactions Using a Sub-regional Model of Housing Markets in England. Progress in Planning, 2016, 104, 1-35.

Caistor-Arendar, L., S. Woodcraft, E. Nielsen, N Bacon, and T. Dixon. Measuring the Social Impacts of Regeneration in South Acton. Countryside Properties, London, 2017.

Callway, R., T. Dixon, and D. Nikolic. Embedding Green Infrastructure Evaluation in Neighbourhood Masterplans-Does BREEAM Communities Change Anything? Journal of Environmental Planning and Management, 2019. DOI: 10.1080/ 09640568.2018.1563371.

Carmona, M., S. Tiesdell, T. Heath, and T. Oc. Public Places Urban Spaces, The Dimensions of Urban Design. Second edition. Oxford: Architectural Press, 2010.

Cheshire, P. Policies for Mixed Communities: Faith-based Displacement Activity? International Regional Science Review, 2009, 32:3, 343-75.

Chiu, R.L.H. Social Sustainability, Sustainable Development and Housing Development. In: Housing and Social Change: East-West Perspectives, R. Forrest and J. Lee (eds.). London: Routledge, 2003, 221-39.

CIH. New Approaches to Delivering Social Value. London: Chartered Institute of Housing, 2015 .

Colantonio, A. Social Sustainability: Linking Research to Policy and Practice, Oxford Institute for Sustainable Development, Oxford Brookes University. Oxford, 2009a.

Social Sustainability: A Review and Critique of Traditional versus Emerging Themes and Assessment Methods. In: SUE-Mot Conference 2009: Second International Conference on Whole Life Urban Sustainability and its Assessment: Conference Proceedings, M. Horner, A. Price, J. Bebbington, and R. Emmanuel (eds.). Loughborough: Loughborough University, 2009b, 865-85.

Colantonio, A. and T. Dixon. Urban Regeneration and Social Sustainability: Best Practice from European Cities. Chichester: Wiley-Blackwell, 2011.

Countryside Properties. Your Acton Gardens: FAQs. Accessed November 2017 at: http:// www.yoursouthacton.co.uk/, 2017.

Cuthill, M. The Contribution of Human and Social Capital to Building Community Wellbeing: A Research Agenda Relating to Citizen Participation in Local Governance in Australia. Urban Policy and Research, 2003, 21:4, 373-91.

—. Strengthening the "Social" in Sustainable Development: Developing a Conceptual Framework for Social Sustainability in a Rapid Urban Growth Region in Australia. Sustainable Development, 2010, 18:6, 362-73.

Davidson, M. and L. Lees. New-Build "Gentrification" and London's Riverside Renaissance. Environment and Planning A, 2005, 37:7, 1165-90.

DCLG. Valuing the Benefits of Regeneration. Economics Paper 7: Volume I-Final Report. DCLG: London, 2010a.

- Valuing the Benefits of Regeneration. Economics Paper 7: Volume II-Logic Chains and Literature Review. DCLG: London, 2010b.

—. National Planning Policy Framework. DCLG: London, 2012.

- Estate Regeneration National Strategy. DCLG: London. Accessed March 2018 at: https://www.gov.uk/guidance/estate-regeneration-national-strategy, 2016.

Dempsey, N, G. Bramley, S. Power, and C. Brown. The Social Dimension of Sustainable Development: Defining Urban Social Sustainability. Sustainable Development, 2011, 19:5, 289-300. 
Dixon, T. and S. Woodcraft. Creating Strong Communities-Measuring Social Sustainability in New Housing Development. Town and Country Planning, November 2013, 473-80.

Dixon, T., N Bacon, I. Caistor-Arendar, E. Nielsen, R. Callway, and A. Naylor. Measuring the Initial Social Sustainability Impacts of Estate Regeneration: A Case Study of Acton Gardens, London. Journal of Sustainability Research, 2019, 1:1, e190002.

DNGB. DNGB in Denmark. Accessed March 2019 at: https://www.dk-gbc.dk/english/ dgnb-in-denmark/, 2019.

Elmer, S. and G. Dening. The London Clearances. City, 2016, 20:2, 271-77.

Florman, M., R. Klinger-Vidra, and M. Facada. A Critical Evaluation of Social Impact Assessment Methodologies and a Call to Measure Economic and Social Impact Holistically through the External Rate of Return Platform. LSE Enterprise Working Paper No. 1602. London, 2016.

Flynn, J. Complete Control: Developers, Financial Viability and Regeneration at the Elephant and Castle. City, 2016, 20:2, 278-86.

Greenwood, D., A. Congreve, and M. King. Streamlining or Watering Down? Assessing the Smartness of Policy and Standards for the Promotion of Low and Zero Carbon Homes in England 2010-15. Energy Policy, 2017, 110, 490-99.

Hall, S. Between State and Market: A Brief History of Urban Regeneration in England. In: En Finir Avec Les Banlieues? Le Désenchantement de la Politique de la Ville, T. Kirszbaum, (ed.). Paris: Les Editions de l'aube, 2015, 117-29.

HCA/JLL. Joining the Dots. Next Generation Benchmark Report. Homes and Communities Agency/JLL: London, 2015.

- Putting People at the Heart of Sustainability. Next Generation Benchmark Report. Homes and Communities Agency/JLL: London, 2015.

Hediger, W. Sustainable Development and Social Welfare. Ecological Economics, 2000, $32: 3,481-92$.

Higham, A., C. Barlow, C. Bichard, and A. Richards. Valuing Sustainable Change in the Built Environment: Using SUROI to Appraise Built Environment Projects. Journal of Facilities Management, 2018, 16:3, 315-53.

Laposa, S. and S. Villupuram. Corporate Real Estate and Corporate Sustainability Reporting: An Examination and Critique of Current Standards. Journal of Sustainable Real Estate, 2010, 2:1, 23-49.

Lees, L. The Death of Sustainable Communities in London? In: Sustainable London: The Future of a Global City, R. Imrie and L. Lees (eds.). Bristol: Policy Press, 2014a.

- The Urban Injustices of New Labour's "New Urban Renewal": The Case of the Aylesbury Estate in London. Antipode, 201b, 46:4, 921-47.

Mayor of London. Better Homes for Better People: The Mayor's Good Practice Guide to Estate Regeneration. Greater London Authority, 2018.

Nase, I., J. Berry, and A. Adair. Urban Design Quality and Real Estate Value: In Search of a Methodological Framework. Journal of Urban Design, 2015, 20:5, 563-81.

Office of the Deputy Prime Minister (ODPM). Sustainable Communities Plan. London: ODPM, 2003.

- Planning Policy Statement 1-Delivering Sustainable Communities. London: ODPM, 2005.

Osmani, M. and A. O'Reilly. Feasibility of Zero Carbon Homes in England by 2016: A House Builder's Perspective. Building and Environment, 2009, 44:9, 1917-24. 
Payne, S., D. Adams, and C. Watkins. Corporate Social Responsibility and the U.K. Housebuilding Industry. In: Corporate Social Responsibility in the Construction Industry, M. Murray and A. Dainty (eds.). London: Taylor and Francis, 2008, 235-58.

Polese, M. and R. Stren (eds.). The Social Sustainability of Cities: Diversity and the Management of Change. Toronto: University of Toronto Press, 2000.

Provan, B., A. Belotti, and A. Power. Moving On Without Moving Out: The Impacts of Regeneration on the Rayners Lane Estate. CASE Report 100. London School of Economics, Centre for Analysis of Social Exclusion, 2016.

Raco, M. Securing Sustainable Communities: Citizenship, Safety and Sustainability in the New Urban Planning. European Urban and Regional Studies, 2007, 14:4, 305-20.

—. From Expectations to Aspirations: State Modernisation, Urban Policy, and the Existential Politics of Welfare in the U.K. Political Geography, 2009, 28, 436-54.

Raman, S. Designing a Liveable Compact City. Physical Forms of City and Social Life in Urban Neighbourhoods. Built Environment, 2010, 36:1, 63-80.

Redrow. Valuing Communities: Communities Report 2018. Redrow, London. Accessed April 2019 at: https://www.redrowplc.co.uk/media/2409/communities-report.pdf, 2018.

RICS. Placemaking and Value. London: RICS, 2016.

Serin, B., T. Kenny, J. White, and F. Samuel. Design Value at the Neighbourhood Scale. CACHE Working Paper. Accessed February 2019 at: https://housingevidence.ac.uk/ publications/design-value-at-the-neighbourhood-scale/, 2018.

Severson, M. and E. de Vos. A Measurement Framework: Social Sustainability in Social and Affordable Housing. Paper presented at Partnerships for Affordable Rental Housing, University of Calgary, November 15-17, 2018.

Sharifi, A. and A. Murayama. A Critical Review of Seven Selected Neighbourhood Sustainability Assessment Tools. Environmental Impact Assessment Review, 2013, 38, 73 87.

Shirazi, M.R. and R. Keivani. Critical Reflections on the Theory and Practice of Social Sustainability in the Built Environment-A Meta-analysis. Local Environment, 2017, 22: $12,1526-45$.

- The Triad of Social Sustainability: Defining and Measuring Social Sustainability of Urban Neighbourhoods. Urban Research and Practice, May 8, 2018.

Social Life. The Social Impact of the Regeneration of Acton Gardens. Countryside Properties, 2019.

Stender, M. and A. Walter. The Role of Social Sustainability in Building Assessment. Building Research and Information, 2018.

Sullivan, L., Y. Rydin, and C. Buchanan. Neighbourhood Sustainability Frameworks-A Literature Review: Frameworks for Assessing the Sustainability of the Built Environment with a Focus at the Neighbourhood Level. UCL Working Paper 001. UCL Centre for Urban Sustainability and Resilience, 2014.

Supply Chain Sustainability School. Social Value and Design of the Built Environment. Supply Chain Sustainability School: London. Accessed March 2018 at: https:// www.supplychainschool.co.uk/documents/social\%20value\%20and\%20design\%20of\%20 the\%20built\%20environment\%20v\%2002\%20oct\%202017.pdf, 2017.

Tyler, P., C. Warnock, A. Provins, and B. Lanz. Valuing the Benefits of Urban Regeneration. Urban Studies, 2013, 50:1, 169-190.

UKGBC. Social Value in New Development: An Introductory Guide for Local Authorities and Development Teams. London: UKGBC, 2018. 
- Universities Research Forum on Social Value. Accessed on February 2019 at: https: //www.ukgbc.org/wp-content/uploads/2018/03/Social-Value-Universities-ResearchForum-write-up.pdf, 2019.

Vallance, S., H.C. Perkins, and J.E. Dixon. What is Social Sustainability? A Clarification of Concepts. Geoforum, 2011, 42:3, 342-48.

Van Kempen, R., K. Dekker, S. Hall, and I. Tosics. Restructuring Large Housing Estates in Europe. Bristol: Policy Press, 2005.

Vine, J., M.K. Rallings Adams, C. Knudesen, R. Lawton, and D. Fujiwara. Valuing Housing and Local Environment Improvements using the Wellbeing Valuation Method and the English Housing Survey. London: HACT, 2017.

Watson, K. and T. Whitley. Applying Social Return on Investment (SROI) to the Built Environment. Building Research \& Information, 2017, 45:8, 875-91.

Watson, K., J. Evans, A. Karvonen, and T. Whitley. Capturing the Social Value of Buildings: the Promise of Social Return on Investment (SROI). Building and Environment, 2016, 103, 289-301.

Watt, P. and A. Minton. London's Housing Crisis and its Activisms. City, 2016, 20:2, 20421.

Weingaertner, C. and Å. Moberg. Exploring Social Sustainability: Learning from Perspectives on Urban Development and Companies and Products. Sustainable Development, 2014, 22:2, 122-33.

Wilkinson, S. Understanding Sustainability and the Australian Property Professions. Journal of Sustainable Real Estate, 2016, 8:1, 95-119.

Wood, C. and D. Deighton. Measuring Social Value the Gap between Policy and Practice. London: NESTA, 2016.

Woodcraft, S. Social Sustainability and New Communities: Moving from Concept to Practice in the U.K. Social and Behavioral Sciences, 2012, 68, 30-42.

—. Reconfiguring the "Social" in Sustainable Development: Community, Citizenship and Innovation in New Urban Neighbourhoods. In: Envisioning Sustainabilities: Towards an Anthropology of Sustainability, F. Murphy, and P. McDonagh, (eds.). Newcastle upon Tyne: Cambridge Scholars Publishing, 2016.

Woodcraft, S., T. Hackett, and L. Caistor-Arendar. Design for Social Sustainability: A Framework for Creating Thriving Communities. London: The Young Foundation, 2011.

Woodcraft, S. and C. Smith. From the Sustainable Community to Prosperous People and Places: Inclusive Change in the Built Environment. In: Sustainable Futures in the Built Environment to 2050: A Foresight Approach to Construction and Development, T. Dixon, J. Connaughton, and S. Green (eds.). Oxford: Wiley Blackwell, 2018.

World Bank. The Initiative on Defining, Monitoring and Measuring Social Capital. Social Capital Initiative Working Paper 1, 1998.

World Commission on Environment and Development (WCED). Our Common Future. Oxford: Oxford University Press, 1987.

Yoo, C. and S. Lee. Neighborhood Built Environments Affecting Social Capital and Social Sustainability in Seoul, Korea. Sustainability, 2016, 8:12, 1-22.

Zheng, H., G. Shen, Y. Song, B. Sun, and J. Hong. Neighbourhood Sustainability in Urban Renewal: An Assessment Framework. Environment and Planning B: Urban Analytics and City Science, 2017, 44:5, 903-24. 
I thank the editors and reviewers for their helpful comments. This paper draws on some of the findings from published reports for U.K. homebuilders to which I contributed as co-author. However, any views expressed in this paper are my own.

All articles published in JOSRE are distributed under the terms of the Creative Commons Attribution License, which permits unrestricted use, distribution, and reproduction in any medium, provided the original author and source are credited.

Tim Dixon, University of Reading, School of the Built Environment, Whiteknights, Reading, RG6 6AY or t.j.dixon@reading.ac.uk. 